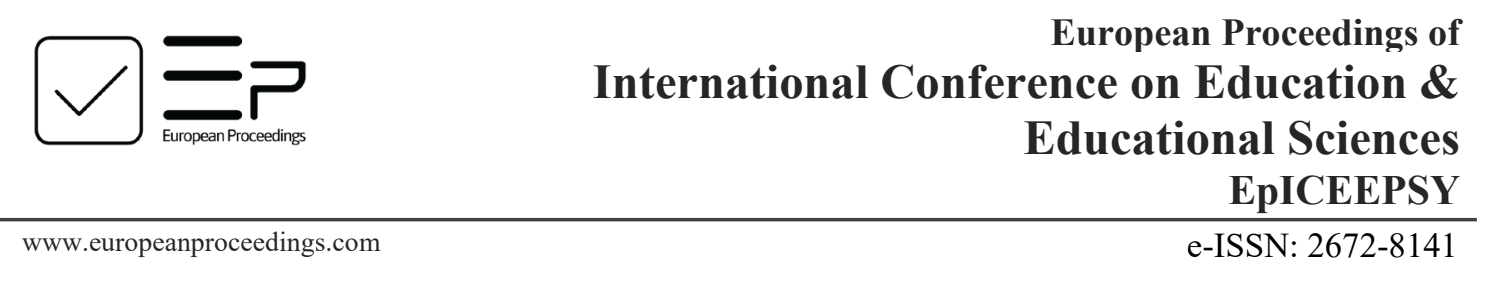

DOI: $10.15405 /$ epiceepsy.20111.1

$11^{\text {th }}$ ICEEPSY 2020

The International Conference on Education and Educational Psychology

\title{
AGE AND PSYCHOLOGICAL APPROACH TO THE STUDY OF STUDENTS' FAMILY SELF-DETERMINATION
}

\author{
Ol'ga Aleksandrovna Karabanova (a), Svetlana Vasil'evna Merzlyakova (b)* \\ *Corresponding author \\ (a) Lomonosov Moscow State University, Faculty of Psychology, 125009, Mokhovaya st. 11/9, Moscow, Russia. \\ okarabanova@mail.ru \\ (b) Astrakhan State University, General and Cognitive Psychology Chair, Tatishcheva St. 20a, Astrakhan, Russia. \\ svetym@yandex.ru
}

\begin{abstract}
Growing-up is characterized by active self-determination in the sphere of marriage and family relations. From the standpoint of the age-psychological approach in the logic of psychological age structure - the social situation of development, new formations and leading activity - the dynamics of the cognitive, valuable-and-emotional, regulative-and-behavioral, motivational and reflective components of family selfdetermination was revealed for the first time in senior teens (from 15 to 16 years old), adolescence (from 17 to 19 years old) and youth (from 20 to 22 years old). In 2012-2019 the study was attended by 1.281 students of Astrakhan State University, the Astrakhan branch of the Russian Presidential Academy of National Economy and Public Administration, a branch of Russian State University for the Humanities in Astrakhan, Astrakhan State Polytechnic College, Astrakhan College of Computer Technology. In senior teens the valuable-and-emotional component prevails. Adolescence is a determining factor in demonstrating cognitive and valuable-and-emotional components. In youth, the cognitive, valuable-andemotional, regulative-and-behavioral, motivational and reflective components are distributed more evenly than in other age-related periods. The age-psychological approach to the analysis of mental development in the ontogenesis makes it possible to consider readiness for family self-determination as a private new formation of adolescence (from 17 to 19 years old), and family self-determination as an important agerelated new formation of youth (from 20 to 22 years old).
\end{abstract}

2672-8141 (C) 2020 Published by European Publisher.

Keywords: Family self-determination, age and psychological approach, psychological age, social situation of development, social context. 


\section{Introduction}

As a result of radical social and economic transformations taking place in the modern world, the institution of family and marriage is being transformed. The age and psychological approach allows to reveal optimal conditions necessary for formation of a family-oriented person, according to a modern sociocultural situation in Russia. In the works of Russian psychologists, mental functional development at the age aspect and the social situation of development are put into a deep analysis. The central importance of teenage and adolescence is generally accepted in forming a worldview, a system of value orientations and personal self-determination (Bozhovich, 2001; Brugman et al., 2003; Dubrovina, 2003; Feldstein, 2004). In Russian psychology, the categories of a social situation of development, new formations and leading activity are used to describe the age and psychological development of a child (L.S. Vygotsky, A.N. Leontiev, D.B. Elkonin, L.I. Bozhovich, O.A. Karabanova, E.I. Zakharova, G.V. Burmenskaya, etc.).

In the structural analysis of a social situation of development, it is appropriate to refer to the concept of «a social context». The social context is understood as "communication and cooperation of a child with a significant social environment within a certain institution of socialization - family, educational establishment, peer group. The child's social environment is a complex, hierarchically organized structure that includes a number of social contexts" (Karabanova, 2012, p. 77). The model of a dynamic structure of a child's social situation of development includes the following elements (Karabanova, 2010, 2012):

$\checkmark$ The child's objective position in the system of social and interpersonal relations;

$\checkmark$ The system of social expectations and requirements setting an «ideal form» of development (L.S. Vygotsky, D.B. Elkonin);

$\checkmark$ The system of guiding images

On the basis of the guiding image, the child's active and effective position with the regard to social reality is implemented. "Guiding image in the unity of its cognitive and affective components performs the function of planning and regulating of implemented forms of joint activity and cooperation, acts as a link, mediating the possibility of developing potential realization of a child's activity" (Karabanova, 2012, p. 78).

The social situation of development in youth is becoming more complex. Children-parents relationships are being transformed and as a result a parent and a child communicate and interact «on equal terms» (Kon, 1989; Feldstein, 2011). The requirements for young people that should be prepared for work, for family life and civic responsibilities, are changing. Kon (1989) notes that "a 18-23-year old person is an adult both biologically and socially. The society sees not so much the object of socialization in him, as the responsible subject of a social and industrial activity, evaluating the results according to "adult" standards" (p. 60). Dubrovina (2015) fairly notes that «the school «lets» young people, who have received general secondary education, into independent life. By the time of graduation, each graduate has his or her own internal (psychological) readiness for life outside the school, as well as self-determination in personal, social, professional and, let us add, «family» areas. Young men and girls, with a worldview formed during their school years, value orientations, idea of the meaning of life and the level of general and psychological culture established, come not only to higher schools, army, work and various institutions. But they also 
come to the Civil Registry Office - to marriage, to create their own family, and to the Maternity Hospitals - to give birth to a new person (Dubrovina, 2015, p. 20).

At each age stage, the social situation of development assigns the main task of development to a child, the solution of which determines the dynamics of mental development at a given age (Karabanova, 2012, p. 76). The concept of developmental task was introduced by Havighurst (1972) and later developed by foreign and native psychologists in detail (Heimans et al., 1995; Khukhlayeva, 2002; Remschmidt, 1994). According to Heimans et al. (1995), developmental task is "a period or a direction of development during which an individual is able to prove or justify to a special jury or audience that he/she is capable of performing certain actions" (p. 8). Developmental tasks should be addressed by young men and girls using the potential they have accumulated in somatic, cognitive and emotional spheres (Remschmidt, 1994).

Thus, the social situation of development provides resources for solving developmental tasks that lead to the appearing of new age-related psychological formations. According to Vygotsky (2003),

new age-related formations should be understood as that new type of personality structure and its activity, those mental and social changes, which appear at a given age level for the first time and which determine the child's consciousness in the most important and basic way, his attitude to the environment, his internal and external life, the whole course of his development at this period. (p. 11)

Vygotsky (2003) supposes that at each age stage there is a central new formation, which leads to the whole process of personal development, and private new formations, which are grouped around the main one, belong to separate sides of a child's personality and are associated with new formations of previous years. "Those developmental processes, which are more or less directly related to the major new formations, will be called central developmental lines at a given age, and all the other partial processes, changes occurring at a given age will be called side developmental lines” (Vygotsky, 2003, p. 23).

According to Spranger, the main new formations of adolescence are: the discovery of Ego, the development of reflection, the awareness of one's own individuality and its properties; the emergence of a life plan, an attitude to the conscious building of one's own life; and the gradual increase in various spheres of life (as cited in Kon, 1989, p. 31).

Describing the youthful age, Bozhovich (2001) is focused on a motivational sphere development of a personality. The whole structure of the personality is determined by its orientation, "which is based on a steadily dominant system of motifs ... The emergence of a hierarchical system of motifs ensures the highest stability of the personality" (p. 237). There is a special personal new formation - self-determination in a second phase of teens (16-17 years old). Bozhovich believes that from the teenager's dreams connected with the future, self-determination differs in that it is based on the already established interests and aspirations of the subject; in that it assumes taking into consideration his or her possibilities and external circumstances; it is based on the emerging worldview of the teenager and is connected with the career choice... Genuine self-determination, i.e. self-determination as a systemic new formation connected with the formation of an adult's inner position, appears much later and is the final last phase of ontogenetic development of a child's personality. Based on the results of studies conducted by Dubrovina (2003), the 
main new psychological formation in early adolescence should be considered not as self-determination by itself, but psychological readiness for self-determination.

From Khukhlayeva's (2002) point of view, one of the important new formations of youth is the achievement of social maturity. It should be understand as "on the one hand, the possibility of fulfilling social duties and, on the other hand, taking responsibility, decisions and actions of one's own life" (p. 23). Thus, this is a possession of a full "complex of social functions of an adult" (Khukhlayeva, 2002, p. 23).

Formation of the basic psychological age-related new formations is provided as a result of leading activity acceptance (D.B. Elkonin, A.N. Leontiev, V.V. Davydov). Nowadays there is no any standard opinion concerning allocation of leading activity of youthful age. The leading activity of 15-17-year old people was considered as the educational and professional activity, through which certain cognitive and professional interests, elements of research skills, ability to make life plans and develop moral ideals, selfconsciousness are formed. Kon (1989) considers that the leading field of activity of late adolescence (18 23-25 years old) is labour, and the education in the university is considered as a type of labour activity.

\section{Problem Statement}

In conjunction with the foregoing, we believe that there is private new formation - psychological readiness for family self-determination, in the period of early adolescence from 17 to 19 years old around the central new formation - self-determination of a personality (Bozhovich, 2001). An important new formation of late adolescence or the beginning of youth (from 20 to 22 years old) is family selfdetermination, which is characterized not only by age-normative characteristics, but also by individualpsychological traits.

A comparative analysis of the characteristics of family self-determination at different ages makes it possible to study the dynamics of marriage and family concepts in ontogenesis, develop measures aimed at fostering family values and cultivating a family way of life among young people, to form a psychological culture in family life and to prevent negative developmental trends.

\section{Research Questions}

Through previous studies components of the structure, content characteristics and types of family self-determination of modern boys and girls have been identified (Merzlyakova, 2018, 2019). It has been established that the indicators of boys' and girls' family self-determination are prescribed by a system of different social-cultural conditions (residence, religion, ethnocultural background, type of a parental family structure, level of a family cohesion, children-parents relationships) and individual-psychological factors (cognitive abilities, typological characteristics of temperament, emotional and volitional properties of a personality, communication abilities and peculiarities of interpersonal interaction).

The following question remains unresolved today: are there any reliable differences in the content and structure characteristics of family self-determination depending on the age of respondents? 


\section{Purpose of the Study}

The aim of the study is to identify the features of family self-determination of student youth at different stages of age development: senior teens (from 15 to 16 years old), adolescence (from 17 to 19 years old) and youth (from 20 to 22 years old). The hypothesis of the research was the assumption that the content and structure characteristics of family self-determination are appointed by the age of the respondents.

The research was conducted on the basis of Astrakhan State University, the Astrakhan branch of the Russian Presidential Academy of National Economy and Public Administration, a branch of Russian State University for the Humanities in Astrakhan, Astrakhan State Polytechnic College, Astrakhan College of Computer Technology. The study was attended by 1.281 students. The age of respondents ranged from 15 to 35 years old. We divided the entire sample into three age groups. The first group was made up of students at the age from 15 to 16 years old - 131 people. (10,2\%). The second group included students aged 17 to 19 years old - 657 people. (51,3\%). The third group included students at the age of 20-22 years old - 457 people (10.2\%). (35,7\%). The remaining correspondence students, whose age varies from 23 to 35 years old - 36 people (35.7\%). (2,8\%).

\section{Research Methods}

5.1. To diagnose content and structure features of family self-determination, we used the modified version of the semantic differential method developed by Ch. Osgood, the questionnaire «The level of correlation between the «value» and «availability» in different areas of life» by E.B. Fantalova, project technique «Unfinished sentences», «Test of life-purpose orientations» by D.A. Leontiev.

5.2. Carrying out the analytical phase, we used mathematical and statistical methods, which allowed us to establish the reliability of the results of the research. All the calculations were done by means of IBM SPSS Statistics 21 . The analysis included descriptive statistics, KolmogorovSmirnov's criterion for one sample, one-way ANOVA for independent samples, KruskalWallis's criterion.

\section{Findings}

Using one-way ANOVA for independent samples (F) and Kruskal-Wallis's non-parametric criterion $(\mathrm{H})$, we evaluated reliability of differences in the content and structure characteristics of family selfdetermination of student youth. In the cognitive component of family self-determination between age groups, differences in statistical significance levels were identified for the variables I-am-a-futurehusband/wife and I-am-a-future-father/mother. From the Table 1 we can see that the value of a functional role of the future spouse increases by 17-19 years old, but decreases by 20-22 years old. Similarly, the role of a future parent has the greatest value at the age of 17 to 19 years old. 
Table 01. Evaluation of the reliability of differences in cognitive component of family self-determination depending on the age of respondents

\begin{tabular}{|l|l|l|l|l|l|}
\hline \multirow{2}{*}{$\begin{array}{l}\text { Structural and content } \\
\text { characteristics of family self- } \\
\text { determination }\end{array}$} & \multicolumn{2}{|l|}{ Median meaning } & Criterion \\
\cline { 2 - 6 } & $\begin{array}{l}\mathbf{1 5 - 1 6} \\
\text { years } \\
\text { old }\end{array}$ & $\begin{array}{l}\mathbf{1 7 - 1 9} \\
\text { years } \\
\text { old }\end{array}$ & $\begin{array}{l}\mathbf{2 0 - 2 2} \\
\text { years old }\end{array}$ & $\begin{array}{l}\text { Significance } \\
\text { level }\end{array}$ \\
\hline I am the future husband/wife & $\mathbf{5 . 5}$ & $\mathbf{6 . 1 7}$ & $\mathbf{6}$ & $\boldsymbol{H}=\mathbf{1 3 . 7 8 2}$ & $\mathbf{0 . 0 0 1}$ \\
\hline I am the future father/mother & $\mathbf{5 . 9 2}$ & $\mathbf{6 . 5}$ & $\mathbf{6 . 3 3}$ & $\boldsymbol{H}=\mathbf{6 . 5 6 6}$ & $\mathbf{0 . 0 3 8}$ \\
\hline I am the head of my family & 5.33 & 5.5 & 5.67 & $\mathrm{H}=5.308$ & 0.070 \\
\hline I am the son/ daughter & 5.5 & 5.83 & 5.67 & $\mathrm{H}=5.092$ & 0.078 \\
\hline
\end{tabular}

The results from Table 2 showing us that the reliable differences in valuable and emotional component of family self-determination have been identified for the variables: marriage, my future family, the value of a happy family life, position of the individual in a family structure, the attitude towards the future marital partner, himself/herself, future children, romantic love, sex, family entertainment and leisure, the efficiency of life, the meaning of life. The median values indicate that between the ages of 15 and 16 there is a more positive attitude towards sex than between the ages of 17-19 and 20-22. By the age of 1719 the importance of marriage values, happy family life, positive attitude to the future marriage partner, who do not lose their importance at the age of 20-22 years old, is increasing. The curvilinear connection, which manifests itself in the fact that indicators are increasing by 17-19 years old but decreasing by 20-22 years old, is noted in such elements of family self-determination as my future family, the position of a person in a family structure, the attitude towards themselves. The indicators of positive attitude towards future children, romantic love and family vacation are decreasing by the age of 20-22 years old among students. Speaking about the efficiency and comprehension of life there is a direct connection with the age. Efficiency of life, satisfaction with self-realization gradually increases by 20-22 years old. A similar trend is observed for the meaningfulness of life.

Table 02. Evaluation of the reliability of differences in indicators of valuable and emotional component of family self-determination depending on the age of respondents

\begin{tabular}{|c|c|c|c|c|c|}
\hline \multirow{2}{*}{$\begin{array}{l}\text { Structural and content } \\
\text { characteristics of family self- } \\
\text { determination }\end{array}$} & \multicolumn{3}{|c|}{ Median meaning } & \multirow{2}{*}{$\begin{array}{l}\text { Criterion } \\
\text { Meaning }\end{array}$} & \multirow{2}{*}{$\begin{array}{l}\text { Significance } \\
\text { level }\end{array}$} \\
\hline & $\begin{array}{l}15-16 \\
\text { years } \\
\text { old }\end{array}$ & $\begin{array}{l}17-19 \\
\text { years } \\
\text { old }\end{array}$ & $\begin{array}{l}20-22 \\
\text { years } \\
\text { old }\end{array}$ & & \\
\hline Family of origin & 6 & 6.17 & 6 & $\mathrm{H}=2.706$ & 0.258 \\
\hline Marriage & 5.58 & 6 & 6 & $H=6.037$ & 0.049 \\
\hline My mother & 6.67 & 6.67 & 6.5 & $\mathrm{H}=2.973$ & 0.226 \\
\hline My father & 5 & 5.67 & 5.5 & $\mathrm{H}=5.555$ & 0.062 \\
\hline My future family & 6 & 6.67 & 6.5 & $H=17.758$ & 0.000 \\
\hline The values of happy family life & 8 & 10 & 10 & $H=22.348$ & 0.000 \\
\hline The value of love & 7 & 8 & 7 & $\mathrm{H}=3.858$ & 0.145 \\
\hline $\begin{array}{l}\text { The value of freedom as } \\
\text { independence }\end{array}$ & 6 & 6 & 6 & $\mathrm{H}=0.380$ & 0.827 \\
\hline Attitude to family & 4 & 4 & 4 & $\mathrm{H}=4.336$ & 0.114 \\
\hline $\begin{array}{l}\text { We are family (attitude to your own } \\
\text { family) }\end{array}$ & 3.5 & 4 & 4 & $\mathrm{H}=4.802$ & 0.091 \\
\hline $\begin{array}{l}\text { Role of an individual in the family } \\
\text { structure }\end{array}$ & 3 & 4 & 3 & $H=8.959$ & 0.011 \\
\hline
\end{tabular}




\begin{tabular}{|l|l|l|l|l|l|}
\hline $\begin{array}{l}\text { Attitude to the future marriage } \\
\text { partner }\end{array}$ & 3 & 4 & 4 & $\boldsymbol{H}=\mathbf{1 1 . 0 4 6}$ & $\mathbf{0 . 0 0 4}$ \\
\hline Self-attitude & $\mathbf{2}$ & $\mathbf{3}$ & $\mathbf{2}$ & $\boldsymbol{H}=\mathbf{1 5 . 9 2 3}$ & $\mathbf{0 . 0 0 0}$ \\
\hline Attitude to future children & 4 & 4 & $\mathbf{3}$ & $\boldsymbol{H}=7.405$ & $\mathbf{0 . 0 2 5}$ \\
\hline Attitude to romantic love & $\mathbf{4}$ & $\mathbf{4}$ & $\mathbf{3}$ & $\boldsymbol{H}=\mathbf{1 0 . 9 7 2}$ & $\mathbf{0 . 0 0 4}$ \\
\hline Attitude to sex & $\mathbf{3}$ & $\mathbf{2}$ & $\mathbf{2}$ & $\boldsymbol{H}=\mathbf{1 0 . 7 0 9}$ & $\mathbf{0 . 0 0 5}$ \\
\hline Attitude to family rest and leisure & $\mathbf{4}$ & 4 & $\mathbf{3 . 5}$ & $\boldsymbol{H}=7.926$ & $\mathbf{0 . 0 1 9}$ \\
\hline Attitude to family of origin & 4 & 3 & 3 & $\mathrm{H}=3.329$ & 0.189 \\
\hline Attitude to mother & 4 & 4 & 4 & $\mathrm{H}=1.959$ & 0.375 \\
\hline Attitude to father & 2 & 2 & 2 & $\mathrm{H}=2.494$ & 0.287 \\
\hline Life goals & 32 & 33 & 33.5 & $\mathrm{H}=3.553$ & 0.169 \\
\hline Life process & 28 & 30 & 30 & $\mathrm{H}=5.787$ & 0.055 \\
\hline Life achievements & $\mathbf{2 5 . 5}$ & $\mathbf{2 7}$ & $\mathbf{2 8}$ & $\boldsymbol{H}=7.129$ & $\mathbf{0 . 0 2 8}$ \\
\hline $\begin{array}{l}\text { General indicator of life } \\
\text { meaningfulness }\end{array}$ & $\mathbf{9 7 . 5}$ & $\mathbf{1 0 4}$ & $\mathbf{1 0 7}$ & $\boldsymbol{H}=\mathbf{8 . 2 0 6}$ & $\mathbf{0 . 0 1 7}$ \\
\hline
\end{tabular}

In the indicators of the regulatory and behavioral component of family self-determination, statistical significance has been identified for such elements as my future, the headship and responsibility in the family, attitude towards divorce, matrimonial conflicts. The median values (Table 3) show us that the value of the future increases by 17-19 years old and remains its importance at the age of 20-22. There is a positive attitude to the family headship and responsibility at the age of 15-16, which decreases then. Feedback has been established between the age and attitude to the divorce, matrimonial conflicts. At the age of 20-22, divorce and matrimonial conflicts are perceived more negatively than at the age of 15-16.

Table 03. Evaluation of the reliability of differences in indicators of regulatory and behavioral component of family self-determination depending on the age of respondents

\begin{tabular}{|c|c|c|c|c|c|}
\hline \multirow{2}{*}{$\begin{array}{l}\text { Structural and content } \\
\text { characteristics of family self- } \\
\text { determination }\end{array}$} & \multicolumn{3}{|c|}{ Median meaning } & \multirow{2}{*}{$\begin{array}{l}\text { Criterion } \\
\text { Meaning }\end{array}$} & \multirow{2}{*}{$\begin{array}{l}\text { Significance } \\
\text { level }\end{array}$} \\
\hline & $\begin{array}{l}15-16 \\
\text { years } \\
\text { old }\end{array}$ & $\begin{array}{l}17-19 \\
\text { years } \\
\text { old }\end{array}$ & $\begin{array}{l}20-22 \\
\text { years } \\
\text { old }\end{array}$ & & \\
\hline My past & 4.82 & 5 & 4.83 & $\mathrm{H}=5.368$ & 0.068 \\
\hline My present & 5 & 5.33 & 5.33 & $\mathrm{H}=5.952$ & 0.051 \\
\hline My future & 5.58 & 6.17 & 6.17 & $H=14.149$ & 0.001 \\
\hline $\begin{array}{l}\text { Accessibility of a "happy family } \\
\text { life" sphere }\end{array}$ & 5 & 5 & 5 & $\mathrm{H}=0.556$ & 0.757 \\
\hline Accessibility of active life & 6 & 6 & 6 & $\mathrm{H}=1.396$ & 0.498 \\
\hline $\begin{array}{l}\text { Accessibility of knowledge (the } \\
\text { possibility of expanding the } \\
\text { education, outlook, common } \\
\text { culture, as well as intellectual } \\
\text { development) }\end{array}$ & 6 & 7 & 6 & $\mathrm{H}=3.273$ & 0.195 \\
\hline $\begin{array}{l}\text { Accessibility of creativity (the } \\
\text { possibility of creative activity) }\end{array}$ & 5 & 5 & 5 & $\mathrm{H}=1.694$ & 0.429 \\
\hline $\begin{array}{l}\text { Headship and responsibility in the } \\
\text { family }\end{array}$ & 5 & 4 & 4 & $H=7.807$ & 0.020 \\
\hline Spouses' rights and duties & 4 & 4 & 4 & $\mathrm{H}=0.128$ & 0.938 \\
\hline Attitude to divorce & -2 & -3 & -4 & $H=30.037$ & 0.000 \\
\hline Attitude to family conflicts & -1 & -2 & -3 & $H=22.052$ & 0.000 \\
\hline
\end{tabular}


The differences at the level of statistical significance in the motivational component of family selfdetermination were established for the following motives: security, success, personal independence, love, material well-being, revenge, recognition by others, self-actualization, happiness (Table 4). By the age of 17-19 the importance of such marital motives as safety, success, love, recognition by others increases and remains unchanged at the age of 20-22. Positive dynamics is noticed for self-actualization. Negative dynamics is typical for such a marriage motive as revenge. Probability of wedding out of a sense of revenge on a former lover or parents decreases with age. Marital motives of personal independence, material wellbeing, happiness reach their maximum at the age of 17-19 years old.

Table 04. Evaluation of reliability of differences in indicators of motivational component of family selfdetermination depending on the age of respondents

\begin{tabular}{|c|c|c|c|c|c|}
\hline \multirow{2}{*}{$\begin{array}{l}\text { Structural and content } \\
\text { characteristics of family self- } \\
\text { determination }\end{array}$} & \multicolumn{3}{|c|}{ Median meaning } & \multirow{2}{*}{$\begin{array}{l}\text { Criterion } \\
\text { Meaning }\end{array}$} & \multirow{2}{*}{$\begin{array}{l}\text { Significance } \\
\text { level }\end{array}$} \\
\hline & $\begin{array}{l}15-16 \\
\text { years } \\
\text { old }\end{array}$ & $\begin{array}{l}17-19 \\
\text { years } \\
\text { old }\end{array}$ & $\begin{array}{l}20-22 \\
\text { years } \\
\text { old }\end{array}$ & & \\
\hline Security & 4.67 & 5.33 & 5.33 & $H=18.097$ & 0.000 \\
\hline Harmonic sexual relations & 6 & 5.83 & 6 & $\mathrm{H}=2.970$ & 0.226 \\
\hline Duty & 4 & 4 & 4 & $\mathrm{H}=0.112$ & 0.946 \\
\hline Achievement of success & 5.5 & 6 & 6 & $H=14.620$ & 0.001 \\
\hline Compensation for feeling lonely & 4 & 3 & 2.83 & $\mathrm{H}=4.466$ & 0.107 \\
\hline $\begin{array}{l}\text { Personal independence ("running } \\
\text { away from parents") }\end{array}$ & 4.83 & 5.67 & 5.5 & $H=15.380$ & 0.000 \\
\hline Love & 5.5 & 6.5 & 6.5 & $H=14.618$ & 0.001 \\
\hline Material wealth & 5.17 & 5.58 & 5.5 & $H=6.823$ & 0.033 \\
\hline Revenge & 4 & 3.17 & 2.67 & $H=16.621$ & 0.000 \\
\hline Communication with people & 5.5 & 5.67 & 5.33 & $\mathrm{H}=3.662$ & 0.160 \\
\hline Social recognition & 5.17 & 5.33 & 5.33 & $H=7.813$ & 0.020 \\
\hline Parenting & 4.83 & 5 & 5 & $\mathrm{H}=4.006$ & 0.135 \\
\hline Self-actualization & 5.25 & 5.67 & 5.83 & $H=6.439$ & 0.040 \\
\hline Happiness & 6 & 6.67 & 6.5 & $H=21.173$ & 0.000 \\
\hline
\end{tabular}

It can be seen from Table 5 that the reliability of differences in the reflexive component of family self-determination has been found for the intrapersonal conflict in the sphere of «happy family life». The degree of the intrapersonal conflict in the sphere of marriage and family life increases by 17-19 years old and does not lose its relevance at the age of 20-22.

Table 05. Evaluation of the reliability of differences in the indicators of the reflexive component of the family self-determination depending on the age of respondents

\begin{tabular}{|c|c|c|c|c|c|}
\hline \multirow{2}{*}{$\begin{array}{l}\text { Structural and content } \\
\text { characteristics of family self- } \\
\text { determination }\end{array}$} & \multicolumn{3}{|c|}{ Median meaning } & \multirow{2}{*}{$\begin{array}{l}\text { Criterion } \\
\text { Meaning }\end{array}$} & \multirow{2}{*}{$\begin{array}{l}\text { Significance } \\
\text { level }\end{array}$} \\
\hline & $\begin{array}{l}15-16 \\
\text { years } \\
\text { old }\end{array}$ & $\begin{array}{l}17-19 \\
\text { years } \\
\text { old }\end{array}$ & $\begin{array}{l}20-22 \\
\text { years } \\
\text { old }\end{array}$ & & \\
\hline I am an image & 5.67 & 5.5 & 5.5 & $\mathrm{H}=0.023$ & 0.988 \\
\hline $\begin{array}{l}\text { Self-confidence (freedom from } \\
\text { internal contradictions, doubts) } \\
\text { (accessibility) }\end{array}$ & 6 & 6 & 6 & $\mathrm{H}=0.724$ & 0.696 \\
\hline Locus of control "Me" & 21 & 22 & 23 & $\mathrm{H}=4.286$ & 0.117 \\
\hline Locus of control "Life" & 28 & 30 & 31 & $\mathrm{H}=5.867$ & 0.053 \\
\hline
\end{tabular}




\begin{tabular}{|l|l|l|l|l|l|}
\hline Self-esteem (MD factor) & 7 & 6 & 7 & $\mathrm{H}=2.136$ & 0.344 \\
\hline $\begin{array}{l}\text { Expressiveness of intrapersonal } \\
\text { conflict in "happy family life" } \\
\text { sphere }\end{array}$ & $\mathbf{1}$ & $\mathbf{2}$ & $\mathbf{2}$ & $\mathbf{H}=\mathbf{6 . 7 0 7}$ & $\mathbf{0 . 0 3 5}$ \\
\hline $\begin{array}{l}\text { The index of mismatch, } \\
\text { disintegration in motivational and } \\
\text { personal sphere }\end{array}$ & 32 & 32 & 30.5 & & \\
\hline
\end{tabular}

So, analyzing the results of the empirical research, we have revealed features of family selfdetermination of student youth depending on the age of respondents. Family self-determination of young people is a changeable dynamic personal formation. Adulthood is characterized by active selfdetermination in the sphere of marriage and family relationships. Age determines the dynamics of cognitive, valuable-and-emotional, regulative-and-behavioral, motivational and reflective components of family selfdetermination.

\section{Conclusion}

The objective aspect of the social situation of development in adolescence is characterized by the fact that society no longer sees him or her as a child but as an adult, both biologically and socially. The system of sociocultural expectations, norms and requirements in youthful age includes completion of education, acquisition of a profession, starting work, financial independence from parents, marriage. Students retain their dependent social status longer than working youth. The subjective aspect of a social situation of development consists of the guiding images system in such aspects as inner position (selfdetermination), self-image, image of a partner and image of interpersonal relations with him (Karabanova, 2012). One of the tasks of development in youthful age is readiness for marriage. The inner position of young men and girls includes the normative image of a family man's personality and the value and meaning attitude to the family way of life. Mastering of a new social position of a family member involves taking new family roles (I-am-a-future- husband/wife, I-am-a-future-father/mother, etc.). Orienting image of a marital partner consists of perceptions of the social expectations of a partner, expectations of the partner (ideal spouse, ideal parent), cognitive image of a partner (what qualities the future spouse should have), affective attitude towards him and the image of relations with him. The system of guiding images performs functions of planning and regulation of behavior in the sphere of marriage and family relations.

The age and psychological approach, which considers the social situation of development as a hierarchy of social contexts, that define the vector and peculiarities of central and private new formations development, reveals the possibility of studying the role of the indicative activity in the system of social and interpersonal relationships in the formation of family self-determination of growing up man. The age and psychological approach to the analysis of mental development in ontogenesis allows to consider the readiness for family self-determination as a private new formation of adolescence (from 17 to 19 years old), and family self-determination as an important new formation of youth (from 20 to 22 years old). Growing up is characterized by active self-determination in the sphere of marriage and family relations. The development of family self-determination in senior teens, adolescence and youth is characterized by heterochrony of cognitive, valuable-and-emotional, regulative-and-behavioral, motivational and reflective components' formation: in senior teens the valuable-and-emotional component prevails; adolescence is a 
determining factor in the manifestation of cognitive and valuable-and-emotional components; in youth, there is more even distribution of cognitive, valuable-and-emotional, regulative-and-behavioral, motivational and reflective indicators than in other age-related periods. The age-psychological approach allows to proceed from the strategy of stating the course of mental development to the strategy of purposeful social construction (Karabanova, 2018). The revealed negative tendencies of development (at the age of 20-22 there is a decrease in importance of family roles I-am-a-future-husband/wife, I-am-a-futurefather/mother, values «my future family», positive attitude to the position of a personality in a family structure, to himself/herself, future children, romantic love, family entertainment and leisure) require creating conditions for family self-determination formation of modern youth. Such conditions are the way of creating an optimal social situation of development, taking into consideration the role of each of the social contexts (family, educational institutions, peer groups) and age-related stage. In the educational environment of the university, the psychological and pedagogical model of a family self-determination of students (Merzlyakova \& Golubeva, 2018) allows to proceed from the spontaneous, «trial and error» method to the focused formation of self-determination in the marriage and family sphere and compensation of risk factors.

\section{References}

Bozhovich, L. I. (2001). Stages of personality formation in ontogenesis. In Psychology of Development: Chrestomathy (p. 512). Piter.

Brugman, D., Heymans, P. G., Boom, J., Podolskij, A. I., Karabanova, O. A., \& Idobaeva, O. (2003). Perception of moral atmosphere in school and norm transgressive behavior in adolescents: an intervention study. International Journal of Behavioral Development, 27(4), 289-300.

Dubrovina, I. V. (2003). Developmental and pedagogical psychology: Chrestomathy. Academy.

Dubrovina, I. V. (2015). Youth's preparation for family life, or «Forgotten» self-determination. Bulletin of Psychological Practice in Education, 3(44), 17-23.

Feldstein, D. I. (2004). Psychology of Adulthood: Structural and Content Characteristics of Personal Developmental Process. Moscow.

Feldstein, D. I. (2011). A Changing Child in Changing World: Psychological and Educational Problems of the New School. Psychology in Russia: State of the Art, 4, 383-396.

Havighurst, R. J. (1972). Developmental Tasks and Education (3rd ed.). David McKay Company.

Heimans, P. G., Podolsky, A. I., Laak, Y. T., Khautamiaki, Y., Zakharova, E. I., Klinkin, T., Karabanova, O. A., Churbanova, S. M., Romanova, O. L., \& Brugman, G. M. (1995). Processes of Mental Development: in Search of New Approaches. Netherlands Foundation for Basic Research Support (NWO) on the project "Developmental Objectives". Moscow.

Karabanova, O. A. (2010). Social Situation of Child's Development - the Key Concept in Modern Developmental Psychology. Psychology in Russia: State of the Art, 3, 130-153.

Karabanova, O. A. (2012). Orienting image in the structure of child's social situation of development: from L.S. Vigotsky to P.Ya. Galperin. Moscow University Bulletin. Series 14. Psychology, 4, 73-82.

Karabanova, O. A. (2018). Development of the age-psychological approach in modern psychology. Almanac of Institute of Special Education of RAE, 35, 1-13.

Khukhlayeva, O. V. (2002). Psychology of Development: Youth, Maturity, Old Age. Publishing Centre «Academy».

Kon, I. S. (1989). Psychology of early adolescence. Psychological Science - School.

Merzlyakova, S. V., \& Golubeva, M. G. (2018). The Development of Family Self-determination of Student's Youth. The European Proceedings of Social \& Behavioural Sciences, LVI, 395-403. https://doi.org/10.15405/epsbs.2019.02.02.43 
Merzlyakova, S. V. (2018). The Typology of Modern Students' Family Self-determination. The European Proceedings of Social \& Behavioural Sciences, LIII, 486-493. https://doi.org/10.15405/epsbs.2019.01.46

Merzlyakova, S. V. (2019). Family self-determination of young people: structure and determinants: a monograph. Publishing House «Color».

Remschmidt, H. (1994). Teenager and Youth. The Problems of Forming a Person (translated from German). Mir.

Vygotsky, L. S. (2003). Psychology of Child Development. Publishing House Eksmo. 